\title{
Arcybiskupi Cypru w roli przywódców narodu*
}

\author{
The Archbishops of Cyprus as Leaders of the Nation
}

(c) (i) $\bigodot_{\text {ND }}$ http://dx.doi.org/10.12775/KLIO.2015.011

A ndrekos Varnava, urodzony i wychowany w Australii z cypryjskich archiwalnej monografii pt. British Imperialism in Cyprus, 1878-1915. The Inconsequential Possession (Manchester 2009) jest uznawany przez niektórych, przynajmniej cypryjskich i greckich, historyków za obrazoburcę ${ }^{1}$. Szczególne przez tych, którzy uważają, że opisywanie dziejów Cypru ma służyć przede wszystkim „pokrzepieniu serc”. Zainicjowana przez Varnavę seria wydawnicza Cyprus Historical and Contemporary Studies stawia sobie za cel publikację „,nowatorskich” i ,apolitycznych” naukowych monografii, których autorzy potrafią odrzucić „deterministyczne i nacjonalistyczne" spojrzenie na dzieje Cypru.

The Archbishops of Cyprus in the Modern Age: The Changing Role of the Archbishop-Ethnarch, their Identities and Politics jest pierwszym tomem, który ukazał się w tej serii. Varnava do pomocy w przygotowaniu tomu zaprosił Michalisa N. Michaela jako współ-redaktora, oraz pięciu cypryjskich i greckich historyków.

W historiografii dot. Cypru dotychczas praktycznie nie było naukowego opracowania roli arcybiskupów (z wyjątkiem Makariosa III), oprócz kilku, głównie hagiograficznych, przyczynków. Redaktorzy tomu zdawali

* The Archbishops of Cyprus in the Modern Age: The Changing Role of the ArchbishopEthnarch, their Identities and Politics, ed. A. Varnava, M. N. Michael, Cambridge Scholars Publishing, Newcastle upon Tyne 2013, 20 il., ss. 331, ISBN (10): 1-4438-4929-4, ISBN (13): 978-1-4438-4929-6.

${ }^{1}$ Zob. np.: P. M. Kitromilides, Review Article: British Imperialism in Cyprus, "Mediterranean Historical Review" 2011, vol. 26, iss. 12, s. 208-210. 
sobie dobrze sprawę, że zawarte w tomie spojrzenie na rolę arcybiskupów cypryjskich może spotkać się z krytyką, często niemerytoryczną, dlatego zastrzegli we wstępie, że książka „nie jest atakiem na Kościół cypryjski” (s. xi), a jej celem jest jedynie obiektywne przedstawienie historycznych faktów, co powinno dać Kościołowi okazję do nowego spojrzenia na swoją przeszłość na Cyprze.

Kościół cypryjski ma specjalne miejsce w rodzinie kościołów prawosławnych, dlatego szkoda, że redaktorzy nie zdecydowali się na przynajmniej krótkie - i oparte nie tyle na powszechnie znanej tradycji, co na ostatnich badaniach naukowych - streszczenie jego historii ${ }^{2}$. Po wprowadzeniu na Cyprze chrześcijaństwa przez apostołów Pawła, urodzonego na Cyprze Józefa, zwanego Barnaba, i jego kuzyna Marka Ewangelistę ${ }^{3}$ tutejszy Kościół uzyskał w 431 roku na soborze w Efezie prawo niezależnego i autonomicznego wyboru arcybiskupa. Sławny ósmy kanon ogłoszony przez sobór nie był równoznaczny z nadaniem autokefalii ${ }^{4}$, ale - podobnie jak później w przypadku macedońskiej Ochrydy i Kijowa - Kościół cypryjski miał stać się rodzajem patriarchatu bez tytułu patriarchy dla arcybiskupa ${ }^{5}$.

Jednak głównym zamierzeniem autorów tomu było nie tyle przyjrzenie się całej historii Kościoła prawosławnego na Cyprze, ile raczej próba napisania „historii politycznej hierarchów” (s. xii) i ich roli jako etnarchów.

Rola etnarchy związana jest z historią Cypru pod panowaniem tureckim $^{6}$. Autorzy przyznają, że historiografia związana z rolą arcybiskupa-

2 Szerzej nt. kościoła na Cyprze zob.: M. Misztal, Historia Cypru, Kraków 2013, s. 84-97 (początki), 109-117 (okres bizantyjski), 254-268 (za panowania Lusignanów i Wenecjan).

${ }^{3}$ Dzieje Apostolskie, 4,36; 11,24; 13-15.

${ }^{4}$ Autokefalii, czyli - jak to rozumiano w IV w. - prawa do niezależności w wyświęcaniu biskupów. B. Englezakis, Epiphanius of Salamis, the Father of the Cypriot Autocephaly, [w:] idem, Studies on the History of the Church of Cyprus, 4-20 Centuries, Aldershot: Variorum 1995, s. 36-39.

5 Kanon 8, [w:] Greek Texts of the Fourth to Thirteenth Centuries, red. H. A. Pohlsander, Sources for the History of Cyprus, t. 7, Albany 1999, nr 19.2; Innocenty I do Patriarchy Antiochii, Epistola, 24.3, [w:] Latin Texts from the First Century B.C. to the Seventeenth Century A.D., red. L. Roberts, Sources for the History of Cyprus, t. 8, Albany 2000, s. 51.

${ }^{6}$ Nt. panowania tureckiego na Cyprze zob.: M. Misztal, Historia Cypru, s. 313$333,353-376$. 
-entnarchy na Cyprze praktycznie nie istnieje (s. 3), ale brak w rozdziale wstępnym nawet krótkiego wprowadzenia na temat stosunku Porty do cypryjskiego Kościoła. Przybycie w 1571 roku na wyspę Turków, po prawie czterech wiekach rządów łacińskich Franków, a potem Wenecjan, oznaczało dla Kościoła katolickiego na Cyprze praktyczną zagładę, ale dla Kościoła prawosławnego rozpoczynało okres odrodzenia. Pod warunkiem płacenia haraczu wszyscy poddani sułtana, raja (tur. reaya, '[ludzkie] bydło'), otrzymali prawo wyznawania swojej religii. Turcy nie interesowali się wewnętrznymi sprawami Kościoła i bez większych problemów wystawiali wymagane zatwierdzenie (berat) wyboru poszczególnych biskupów ${ }^{7}$. Berat miał podobną funkcję jak średniowieczna inwestytura biskupów przez chrześcijańskich monarchów, z tym że potwierdzał rolę biskupów nie tylko jako liderów Kościoła, lecz również jako cywilnych przywódców, a od 1754 roku opiekunów (kojabaşi) i formalnych reprezentantów społeczności wiernych (millet) w kontaktach z Portą ${ }^{8}$. Arcybiskup zaś dzięki beratowi stawał się etnarchą, najwyższym duchowym i politycznym przywódcą oraz opiekunem ortodoksyjnych Cypryjczyków, odpowiedzialnym za ich lojalność w stosunku do sułtana, z prawem składania petycji, skarg i zażaleń bezpośrednio do Porty w Stambule?.

Formalnie urząd etnarchy przestał istnieć w momencie, gdy Wielka Brytania de facto przejęła władzę na Cyprze w 1878 roku Brytyjczycy oficjalnie nie uznawali arcybiskupa za etnarchę, a hierarchia prawosławna straciła władzę i wpływy, jakie miała pod panowaniem tureckim. Jednakże Kościół prawosławny na Cyprze nie przywiązywał większej wagi do zaistniałego prawnego problemu i arcybiskupi byli de facto $\mathrm{w}$ dalszym ciągu 353.

${ }^{7}$ Szerzej nt. kościoła na Cyprze pod panowaniem tureckim zob.: ibidem, s. 333-

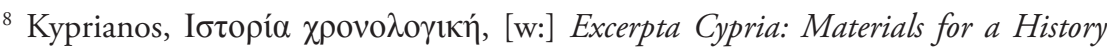
of Cyprus, oprac. C. D. Cobham (Cambridge 1908), s. 349-350, 353-355. Por.: H. F. Alasya, The Privileges Granted to the Orthodox Church of Cyprus by the Ottoman

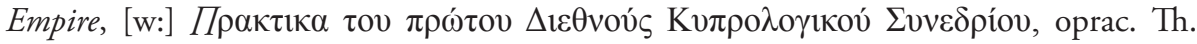
Papadopoullos, M. Christodoulos, Nikosia 1973, 3A: 23-261; G. A. Dionyssiou, Some Privileges of the Church of Cyprus under Ottoman Rule, "Epetiris" 1992, t. 19, s. 327-334.

${ }^{9}$ Por.: berat arcybiskupa Sofroniosa z 1865 r., [w:] Excerpta Cypria, s. 470-474; H. Luke, Cyprus. A Portrait and an Appreciation, London 1957, s. 71, 76. 
przede wszystkim etnarchami, czyli politycznymi przywódcami, których drugorzędną jedynie rolą było przywództwo duchowe. Brytyjski gubernator Storrs wprost stwierdził, że Kościół ortodoksyjny na Cyprze jest instytucją „raczej polityczną niż religijną”. Kiedy Cypr odzyskał niepodległość w 1960 roku, arcybiskup Makarios III, przyjmując urząd prezydenta republiki, przywrócił urząd „etnarchy”, praktycznie znosząc podział na władzę kościelną i świecką.

Tom ogranicza się do przedstawienia postaci dziesięciu arcybiskupów od 1767 roku, czyli początku panowania arcybiskupa Chryzantosa, do 2006 roku, czyli intronizacji arcybiskupa Chryzostoma II, obejmując część okresu tureckiego (1571-1878), okres brytyjski (1878-1960) i okres niepodległości (od 1960). Analiza działalności poszczególnych arcybiskupów pokazuje, że ich rola zmieniała się w tym okresie i podaje w wątpliwość ogólnie przyjęty „deterministyczny” punkt widzenia, że głównym celem arcybiskupów Cypru było reprezentowanie i wspomaganie nacjonalistycznych dążeń ortodoksyjnych greckich Cypryjczyków, które koncentrowały się na zachowaniu helleńskiego dziedzictwa ${ }^{10}$.

Najciekawsze są rozdziały, które stawiają w nowym (krytycznym) świetle arcybiskupów mających już tradycyjnie ustalone miejsce w podręcznikach szkolnych, głównie jako liderów nacjonalistycznych dążeń greckich Cypryjczyków.

Rozdział poświęcony arcybiskupowi Kyprianosowi (1810-1821) napisał Michalis N. Michael. Kyprianos ma zapewnione miejsce w nacjonali-

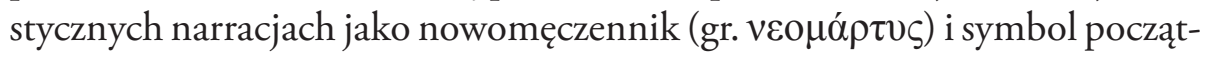
ków walki greckich Cypryjczyków o enosis, połączenie z grecką Macierzą,

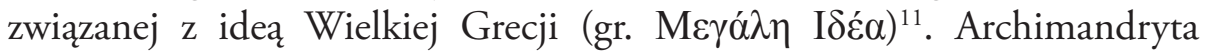
Benedict Englezakis, jeden z nielicznych cypryjskich badaczy Kościoła, dla którego fakty były ważniejsze niż afiliacja religijna, pisał jednak, że Kyprianos „zapewnił sobie miejsce w historii nie dzięki swojemu życiu i uczynkom, ale

${ }^{10}$ Por.: Theodore Papadopoullos, Orthodox Church and Civil Authority, "Journal of Contemporary History” 1967(October), vol. 2, s. 201-209.

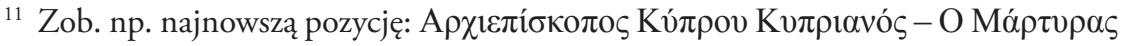

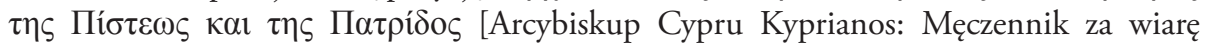
i ojczyznę], red. P. Agathonos (Nikozja: Machairas Monastery, 2009); publikacja jest jednak ważna choćby dlatego, że zawiera zachowane listy i dokumenty związane z Kyprianosem. 
z powodu swojej ofiary i śmierci"12. Michael zdaje się potwierdzać tę opinię i pokazuje arcybiskupa jako wykształconego, energicznego lidera, który doprowadził do wygnania leciwego arcybiskupa Chryzantosa i bez formalnego kanonicznego wyboru przyjął nominację na arcybiskupa (berat) z rąk sułtana, współpracował z władzami otomańskimi, ale dbał też o własne interesy. Szkoda tylko, że autor nie posiłkuje się w większym stopniu zebranymi np. przez Agathonos zachowanymi materiałami źródłowymi, cytaty z których mogłyby pomóc w weryfikacji prezentowanego punktu widzenia, np. w przypadku zmieniających się w kolejnych listach i dokumentach relacji Kyprianosa ze sposobu uzyskania nominacji na arcybiskupa.

Michael zwraca uwagę na podobieństwo urzędu etnarchy do fanarioty z otomańskiej Wołoszczyzny i Mołdawii oraz na wykorzystywanie przez arcybiskupów symboli bizantyjskich, ale jedynie w przypisie wspomina o sławnych na Cyprze przywilejach arcybiskupów uzyskanych jakoby od cesarza Zenona (s. 50 przypis 33, gdzie błędnie podano datę 470 jako rok panowania cesarza).

W większości historii Cypru można przeczytać, że za panowania cesarza Zenona Izauryjczyka (474-491) jego protegowany patriarcha Antiochii, Piotr (Folusznik), odrzucił ustalenia z Efezu dotyczące autokefalii cypryjskiego Kościoła. Jednak dzięki - jak chce tradycja ${ }^{13}$ - wstawiennictwu samego św. Barnaby, który we śnie wskazał arcybiskupowi Cypru swój grób, w którym spoczywały „zwłoki wydzielające słodki odór świętości”, ściskające w objęciach pokryty pleśnią egzemplarz Ewangelii św. Mateusza w języku hebrajskim, prawa Kościoła na Cyprze zastały potwierdzone, a znalezioną Ewangelię podarowano cesarzowi ${ }^{14}$.

Tradycja cypryjska utrzymuje również, że z wdzięczności za cenny podarek cesarz nadał arcybiskupowi Cypru i jego następcom wyjątkowe przywileje, zwyczajowo przysługujące jedynie cesarzom: podpisywania do-

12 B. Englezakis, Archbishop Kyprianos's Inkstand, [w:] idem, Studies on the History of the Church of Cyprus: $4^{\text {th }}-20^{\text {th }}$ Centuries, ed. S. i M. Ioannou, Aldershot 1995, s. 278.

13 A. Monachus, Laudatio Barnabae (Lobrede auf Barnabas), tłum. B. Kollmann, Turnhout 2007, s. 28/29 (dalej cyt.: Laudatio Barnabae).

${ }_{14}$ Laudatio Barnabae, s. 4.40-41, 44-45, 23; Acta Barnabae, [w:] Greek Texts of the Fourth to Thirteenth Centuries, oprac. H. A. Pohlsander, Albany 1999, nr 25.1-26; Teodor Lektor, Historia kościelna, streszczenie 436, [w:] ibidem, nr 31.6. 
kumentów czerwonym inkaustem, noszenia podczas uroczystości kościelnych szat w kolorze cesarskiej purpury i zastąpienia zwyczajowego pastorału berłem. $Z$ historycznego punktu widzenia nadanie tych przywilejów jest nader wątpliwe, bo mimo ich wyjątkowości nie wspomina o nich ani Laudatio Barnabae, ani żadne bizantyjskie źródło ${ }^{15}$. Prawdopodobnie więc "przywileje cesarskie” zostały uformowane dopiero w okresie panowania Franków ${ }^{16}$, kiedy Kościół prawosławny tracił wpływy i znaczenie na rzecz łacinników.

Najważniejszym bodaj ustaleniem Michaela jest wykazanie, że Kyprianos nie tylko nie został członkiem założonego w 1814 roku Stowarzyszenia Przyjaciół (Rewolucjonistów), Filiki Eteria, które propagowało ideę niepodległości Grecji, ale był także daleki od udzielenia im poparcia, a nawet opublikował ostrzeżenie dla wiernych przed kontaktem z reprezentantami organizacji. Mitem jest więc powszechne przekonanie, że Kyprianos był pierwszym bojownikiem o enosis; wręcz przeciwnie, potępiał on wszelkie akty kwestionujące status quo. Konieczna jest więc nowa interpretacja wydarzeń z lipca 1821, w wyniku których stracono nie tylko Kyprianosa i trzech biskupów, ale i 468 wpływowych greckich Cypryjczyków i które oznaczały koniec dominacji cypryjskich biskupów na wyspie ${ }^{17}$.

Ze wszystkich autorów tomu najtrudniejsze zadanie miała Sia Anagnostopoulou, która napisała rozdział o arcybiskupie Makariosie III (1950-1977), który od 1960 roku był również prezydentem Republiki Cypryjskiej. Mimo licznych publikacji na temat Makariosa III nadal nie po-

15 Pierwszy raz wspominane są dopiero w XVII w., a potem przywoływane z dumą w wyraźnie prokościelnej kronice archimandryty Kyprianosa z 1788 r. Kyprianos, I $\sigma \tau$ opí $\alpha$

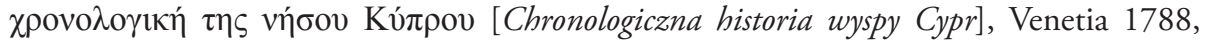
s. 314.

16 Specjalnym papieskim przywilejem łacińscy arcybiskupi Cypru mieli prawo noszenia szat w kolorze kardynalskiej purpury. E. de Lusignan, Chorograffia, oprac. O. Pelosi, Albany 2001, \$167: „'arcivescovo di Cipro, quando e all residential, va vestito tutto di rosso come li Cardinali"; J. Hackett, A History of the Orthodox Church of Cyprus: from the Coming of the Apostles Paul and Barnabas to the Commencement of the British Occupation (A.D. 45-A.D. 1878), London 1910, s. 476.

17 Podobnie: A. Varnava, British Imperialism in Cyprus 1878-1915. The inconsequential possession, Manchester 2009, s. 153-156. 
wstała akademicka, oparta na faktach i materiałach źródłowych, analiza jego działalności ${ }^{18}$. Greckojęzyczne biografie Makariosa są z jednej strony w dużym stopniu hagiograficzne i rozgrzeszają go ze wszystkich zbrodni popełnianych przez rządowe paramilitarne siły greckich Cypryjczyków, z drugiej zaś uznają za oczywiste, że wszyscy (greccy) Cypryjczycy darzyli Makariosa szacunkiem i całkowicie popierali jego działania ${ }^{19}$. Najpoważniejsza anglojęzyczna trylogia dotycząca Makariosa pokazuje go w podobny sposób ${ }^{20}$.

Anagnostopoulou postawiła sobie za cel pokazanie, jak rola etnarchy, do którego to tytułu Makarios oficjalnie nawiązywał, zmieniła się w czasie jego panowania, ewoluując od antykolonialnego przywódcy stawiającego sobie za nadrzędny cel „enosis i tylko enosis”, po prezydenta postkolonialnej republiki, dla którego niepodległość Cypru stała się ważniejsza od zjednoczenia z Grecją. Dla wielu greckich Cypryjczyków to zmiana w podejściu do enosis była nie do zaakceptowania i oznaczała zdradę narodu. Szkoda, że Anagnostopoulou, często cytując wypowiedzi Makariosa, nie zawarła w tekście ważnego przyrzeczenia arcybiskupa złożonego w czasie ingresu: „Składam świętą przysięgę, że będę pracował na rzecz narodzin naszej narodowej niepodległości i nigdy nie odstąpię od naszej polityki zmierzającej do zjednoczenia Cypru z Matką Grecją"21. Podobną przysięgę Makarios złożył

18 Por.: R. Holland, The Historiography of Late Colonial Cyprus: Where Do We Go from Here, [w:] Britain in Cyprus: Colonialism and Post-Colonialism 1878-2006, red. H. Faustmann i N. Peristianis, Mannheim 2006, s. 446-447.

${ }^{19}$ Np. A. Pavlides, Makápıos [Makarios], 3 t., Nicosia 1981, ważna jednak choć-

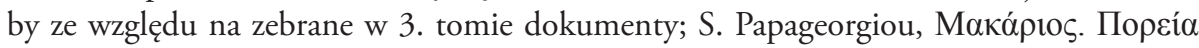

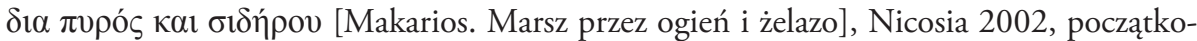
wo współpracownik Grivasa, koncentruje się na spiskach, które doprowadziły do coup przeciwko Makariosowi. Podobnie anglojęzyczne opracowania i artykuły napisane przez cypryjskich historyków, np. D. Alastos, Cyprus Guerrilla: Makarios, Grivas and the British, London 1960; S. Soulioti, Fettered Independence, 1878-1964, 2 t., Minneapolis 2006; Ch. Kassimeris, A. Philaretou, Playing Politics with Charisma: Archbishop Makarios III and the Cyprus Issue, "Politics, Culture and Socialization" 2010, vol. 1, iss. 4, s. 337-352.

${ }^{20}$ P. N. Vanezis, Makarios: Faith and Power, London 1971; idem, Makarios: Pragmatism vs. Idealism, London 1974; idem, Makarios: Life and Leadership, London 1979. Wyjątkiem opracowanie autorstwa S. Mayes, Makarios. A Biography, London 1981, oparte w dużej mierze na wspomnieniach znajomych i współpracowników Makariosa.

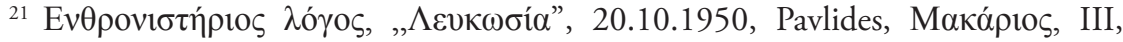
$41-2$. 
w kościele Faneromeni w sierpniu 1954 roku, kończąc ją słowami „enosis i tylko enosis" ${ }^{22}$, ale już rok później, we wrześniu 1955, po raz pierwszy dopuścił możliwość współpracy z Brytyjczykami nad konstytucją zmierzającą do wprowadzenia na Cyprze okresu autonomicznych rządów, które z kolei miały doprowadzić do niepodległości kraju.

Anagnostopoulu pomija milczeniem rozterki Makariosa związane z podpisaniem ustaleń konferencji z Zurychu i Londynu, które oznaczały uzyskanie przez Cypr niepodległości ${ }^{23}$. Autorka wnioskuje, że według Makariosa celem narodu było nadal enosis, ale celem kraju była wolność i polityka niezaangażowania. Jednak takie tłumaczenie nie przekonywało przeciwników Makariosa, który od momentu powstania Republiki Cypryjskiej musiał stawić czoła nie tylko mniejszości tureckich Cypryjczyków, ale również swoim greko-cypryjskim przeciwnikom uznającym go za zdrajcę narodowych dążeń narodu, co w praktyce doprowadziło do próby obalenia Makariosa za pomocą greckiej junty i - pośrednio - do zajęcia jednej trzeciej Cypru przez wojska tureckie.

Autorka nie odnosi się do jednej z najważniejszych kontrowersji związanych z działalnością Makariosa w dążeniu do enosis, mianowicie do jego odpowiedzialności za akty terroru wymierzone również w greckich Cypryjczyków, organizowane przez popieraną przez arcybiskupa Narodową

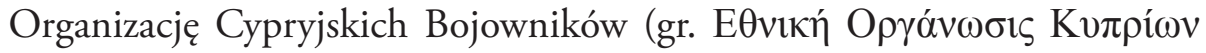
A zginęło na Cyprze 238 cywilów, z których 203 było greckimi, 7 tureckimi Cypryjczykami, 26 Brytyjczykami, 2 innych narodowości, a 288 cywilów odniosło rany ${ }^{24}$.

Inaczej niż pozostali autorzy tomu, w swojej dyskusji autorka opiera się głównie na drukowanych materiałach (przemówieniach i oficjal-

22 Ibidem, III: 156-8.

23 Por.: National Archives (Kew), FO 371/144641: Verbatim Reports of the First, Second and Third Plenary Sessions at Lancaster House, 17-19 II 1959.

${ }^{24}$ EOKA and Archbishop Makarios. Revelations in captured documents, National Archives, FCO 141/4352, 26 VIII 1956, Ściśle tajne, f. 56-63; Gubernator Harding do Ministra Spraw Zagranicznych, NA FCO 141/4353, 6 IX 1956, Ścisle tajne, f. 104-5; nt. dyskusji dot. formalnego oskarżenia Makariosa o działalność terrorystyczną zob.: ibidem, f. 103. Por.: A. Varnavas, A History of the Liberation Struggle of EOKA, Nicosia 2004. 
nych listach Makariosa) oraz na kilku nie najnowszych już opracowaniach (np. Kranidiotis ${ }^{25}$ ), z rzadka jedynie cytując materiały archiwalne, przede wszystkim streszczenia z „Bulletin de Renseignements Politiques” $\mathrm{z}$ ateńskich Archives du Ministère des Affaires Etrangères, Europe-Grèce, Présidence du Conseil. Kwerenda w archiwach cypryjskich (np. Secretariat Archives w Nikozji) czy brytyjskich, które kilka razy w roku udostępniają nowe dokumenty dotyczące działalności Makariosa, z pewnością pomogłaby w ustaleniu nieznanych faktów i otworzyła możliwość nowych interpretacji. Nota bene, w krótkiej bibliografii zamieszczanej na końcu tomu brak wykorzystywanych w książce źródeł archiwalnych.

Podsumowując, jest to ważna książka, która jeśli nawet nie rozwiewa wszystkich mitów dotyczących poszczególnych arcybiskupów, które narosły w historiografii Cypru, i nie odpowiada do końca na wszystkie postawione pytania, jest ważnym głosem w dyskusji na temat roli cypryjskiego Kościoła w życiu politycznym wyspy. Niektóre z zaproponowanych intepretacji (np. oskarżających Kościoł o reprezentowanie „szowinistycznej odmiany cypryjskiego hellenizmu", s. 16) mogą wywołać protesty prawicowych greckich Cypryjczyków, ale powinny też dać początek merytorycznej, akademickiej dyskusji opartej na dokładnej analizie zachowanych dokumentów.

Mariusz Misztal

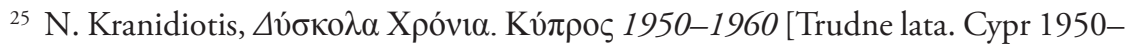
-1960], Estia Athens 1981. 